\title{
Coordination Practices in Hungary: The Case of Széll Kálmán Working Group
}

\author{
György Hajnal
}

\section{Introduction}

The newly elected Orbán cabinet that entered into office following the landslide election victory in May 2010 found itself caught in a situation requiring deep and instant structural changes to the public household. As Figure 19.1 shows, the long-term negative trend of the fiscal balance trespassed, as a consequence of the ensuing fiscal and economic crisis of 2008, the threshold of sustainability. The two action plans announced in the first months of the new administration contained only some short-term fire alarm measures. A direr problem was achieving systemic and longer-term changes, particularly on the expenditure side, within the very short time frame available and at less than prohibitive political costs. Such measures were devised only by the Széll Kálmán Plan (SKP) announced in March 2011 (Government of Hungary 2011).

Figure 19.1 Public debt and budget deficit in Hungary, 2001-12

\section{Source: EUROSTAT.}

The SKP included 26 goals ranging from re-designing a broad range of social benefits to reshuffling the public transport system and to decreasing the number of MPs from 386 to 200 from the next election. The SKP itself contained only a very brief description of measures, all of which required, however, close collaboration between a broad range of central government actors. The goal of the Széll Kálmán Working Group (SKWG) was to coordinate the complex task of implementing the SKP. This case description reviews the context, the core elements, the process and the results of this coordination arrangement.

Since documentary evidence, systematic and published analysis and assessment of the Working Group's operation were very scarce, the chapter mostly builds on in-depth interviews with key informants who participated in the process. In addition, basic pieces of legislation and published and unpublished government reports/documents served as the empirical basis of the research. 


\section{Country and policy field background}

Hungary is a unitary, parliamentary republic. The Hungarian administrative structure comprises three levels: central, territorial (county) and local level. The central government system is divided into ministries and various agencies, many of the latter having field offices in county or even lower (local) administrative levels and employing a significant share of civil servants. This variety of middle-tier administrative organizations, together with the elected, county self-governments and their administrations, constitutes the middle tier of public administration. At the lowest level, Hungary's territory is divided into more than 3,000 locally elected, municipal self-governments and 200 centrally supervised, administrative districts, from 2013 onwards.

The Széll Kálmán Working Group could best be understood in the context of two key contextual factors extending far beyond the scope of the SKWG. The first was the continuation and the deepening of the fiscal and economic crisis that created a severe need for budgetary emergency management. The second is associated with the tectonic shift in the Hungarian political system, which occurred after the 2010 defeat of the Socialist-Liberal coalition and the landslide victory that resulted in a parliamentary supermajority of the Centre-Right FIDESZKNDP coalition. ${ }^{1}$ This shift in politics resulted in a swift and fundamental institutional and constitutional redesign of political and administrative institutions. The observed features of the emerging system are characterized in international political science literature, varyingly, as illiberal (Bánkuti et al., 2012), autocratic (Scheppele, 2013) or - from a narrower, administrative point of view - strongly centralizing (Kornai, 2012; Hajnal and Kovács 2013).

The SKWG can be seen as an innovation, induced by the needs of budgetary crisis management, in central governmental coordination. Therefore, it is necessary to briefly review the developments that took place in the field of inter- and intra-ministry coordination in the preceding two decades.

In the period between 1990 and the present, management in central government was characterized by recurring and increasingly successful attempts at strengthening hierarchical coordination. In this process four important milestones can be identified.

The first milestone occurred in December 1990 with the setting up of an administrative consultation process among the ministries. At the top was a new Council of Permanent State Secretaries, which was composed of ministries' highest ranking administrative officials. Until 2006, the Council met once per week to discuss and possibly approve any items on the agenda of a next Cabinet Meeting. 
The second milestone was the Orbán's first Cabinet's 1998 reform of the Prime Minister's Office (PMO). This involved a definitive strengthening of the PMO's authority over ministries. The core change was the creation of a structure mirroring the ministry structure within the PMO, whereby each mirror department was entitled to examine/filter/reject initiatives coming from the respective ministry before it could get to the Cabinet's agenda.

The third milestone was a set of closely interrelated measures introduced in early 2006. By and large, these measures were labelled as the 'strengthening of political governance'. Changes comprised the abolition of the position of permanent state secretaries and their corresponding Council and replacing it with a similar, but more explicitly political framework that included, among others, several politically appointed state secretaries and deputy state secretaries from each ministry.

Finally in 2010, Orbán's second Cabinet abandoned the 2006 innovations. Instead, the pre-2006 arrangements of Permanent State Secretaries were re-introduced. This step was probably motivated by the degradation of ministries' internal management system, which had ensued as a consequence of the 2006 elimination of the clearer bureaucratic structure topped by permanent state secretaries. The stated goal of reintroducing a clearer separation between politics and administration played, in the view of the broader context of the government's administrative policy characterized by an almost unlimited strife to enhance political control and politicization, no role (Hajnal and Csengődi, 2014).

Thus, most governmental efforts at improving coordination were limited to a narrow set of measures focusing entirely on the strengthening of the PMO's (or its equivalent) control over ministries. Other instruments often appearing in countries of Western/Northern Europe or North America - such as non-bureaucratic coordination mechanisms and horizontal coordination arrangements (Bouckaert et al., 2010; 6 2003; Thompson et al., 1991/1998) - were almost entirely absent.

Whatever the role and power of the political centre, the normal process of policy coordination in central government - both before and after 2010 - was composed of a series of events involving administrative consultations between ministries, with social partners and the broader public, and the approval or modification by the Council of Permanent State Secretaries. This procedure was less apt for the rapid implementation of decisions made in a top-down style, particularly if they involved several ministerial/sectoral stakeholders with high stakes and/or politically highly controversial issues. 


\section{The Széll Kálmán Working Group}

\section{Background and initiation}

The SKP - the centrepiece of the government austerity management program - was elaborated in the Ministry of National Economy in early 2011. The SKP was a novel type of policy document in Hungarian governmental practice in that it attempted to specify, explain and justify quite a broad scope and grievous set of austerity measures in a popular, easily accessible and politically openly combative way (involving a possible maximum of shifting blame to previous governments).

From a substantive perspective, the SKP contained only a concise, usually one-sentence description of measures to be initiated. The detailed content - that is, the specific way in which the budget cut in the given field should be achieved - was to be elaborated in a next phase of the decision-making process, necessarily involving the collaboration of several ministries and ministry departments. Note that the actual monitoring of the implementation of these measures, let alone the monitoring of the effects of the measures, was entirely absent from the SKP concept.

The various items on the SKP agenda were conceptualized and formulated as an adoption of legal measures rather than actually doing or achieving things. For example, the reformulated old age pension system did not appear in the SKP as a set of institutions and procedures operating in a specific way and to a particular effect. Instead, it assumed that 'By December 31, 2012, we codify the legal measures necessary for the operation of the new old age pension system.'

The most important expenditure reduction measures of the SKP included the following:

- Revision of the disability benefit system (disability benefits amounted to more than 2 per cent of the GDP in 2008, which is by European comparison exceptionally high).

- Revision of the early retirement system (early retirement schemes were in place in a number of professions, including police and firemen forces) and incentivizing the return of early retirees into the job market.

- Restructuring of large public transport corporations (the Hungarian Rail and the Budapest Public Transport Corporation).

- Centralization of public education and decreasing the upper end of compulsory school age from 18 to 15 years.

- Restructuring of the higher education, including a radical decrease in funding to universities.

- Restructuring/decreasing social security support for medications.

- Constraining credit taking by local self-governments.

- On the revenue front, the priority was an introduction of a new electronic road toll system. 
In order to complete the SKP, in March 2011, the Cabinet called the SKWG into existence, as a temporary arrangement. The first meeting of the SKWG was held in April 2011, and its operations lasted until the end of 2011 when the SKP was determined to be successfully implemented. There was no formal 'last meeting' or closure of the SKWG.

In regard to the stated goals of the SKWG, it is interesting (especially in the Hungarian context characterized by a strongly legalistic thinking) to observe that the SKWG lacked any formal legal authorization or statute. It was established through a Cabinet decision and a set of decisions from the minister of the Ministry of Public Administration and Justice (hereinafter MPAJ: the successor of PMO and the most central and powerful ministry). These decisions were not of a legal nature; therefore, they were not accessible for the present research.

\section{The structure of the SKWG}

The SKWG involved a two-tier framework. On the top level one found the SKWG itself, headed by the Minister of MPAJ and consisting of Permanent State Secretaries from each ministry, a selected set of state secretaries and deputy state secretaries, and the representative of the Cabinet Office. At the lower tier of the structure there were about 16 Expert Working Groups (EWGs). These were set up early on in the process by a decision from the Minister of MPAJ. Each of the groups was led by at least one high-level representative of the affected ministry (ministries) and usually on the state secretary level.

On the basis of the Cabinet and MPAJ Minister's decisions, the technical details of the SKWG were specified by the Deputy State Secretariat for Public Administration Strategy. The SKWG arrangement extensively involved both political and administrative/technical elements. Non-governmental or corporate sector actors appeared only marginally. One of these rare occasions was, for example, when pharmaceutical companies were involved in the work of the EWG working on reducing the health insurance budget for medicines.

The legislative measures for implementing the items of the SKP were to be elaborated in the EWGs and finally approved by the high-level SKWG. The effectiveness and fast operation of the lower-level EWGs was to be ensured by high-level (deputy state secretary or state secretary level) representation of all important governmental stakeholders, which enabled instant decision-making. Most of the tasks requiring substantial technical expertise such as problem analysis, identification and evaluation of alternatives, elaboration of the actual outputs in the form of proposed measures/draft regulations were done at this lower tier. 
There were open conflicts in the working groups at both levels. If the conflict could not be resolved on the lower level then the issue was postponed until the next week's meeting. In the meantime, additional solutions or compromises were investigated. If this did not solve the issue then the head of the high-level SKWG proposed a solution. If this still did not lead to a consensus a Cabinet decision was requested. The frequencies of such conflicts are reflected by the fact that at least one third of the issues were decided by the Cabinet. However, according to participants' views even this ratio was deemed to be a relative success.

The entire system of the SKWG was built upon existing structures and resources. This meant that no new units were set up and no new personnel were hired for this purpose. The administrative tasks were managed by an existing unit within the MPAJ, the Deputy State Secretariat for Public Administration Strategy.

Information and communication technology also played an important role in the SKWG framework. A centralized online platform for planning, scheduling, monitoring and reporting on the activities of working groups, and sharing and reviewing of working documents was utilized.

\section{The operation of the SKWG}

When looking at how and where important decisions during the implementation of the SKP were made, one may differentiate between two key elements: deciding about the financial target numbers that were to be achieved, and elaborating and codifying the ways in which these fiscal targets were to be achieved.

In regard to the first component, key budgetary figures of the SKP - notably kept confidential throughout the process - were devised by the Ministry of National Economy's administrative apparatus and finally approved by the Cabinet Office within the MPAJ. This was a similar practice to that of the previous, pre2010 pattern.

The second stage of the process took place within the SKWG. This involved the following steps. The EWGs first prepared their work plans. These were then approved by the high-level SKWG. Then, actual work within the EWGs commenced, with the groups reporting weekly to the high-level working group. At the end of the work, the results were submitted to the high-level working group. These were either accepted or a revision was requested. If accepted, the proposal was sent to the so-called 'fast-track administrative consultation' and then to the Council of Permanent State Secretaries. If all these stages were successfully passed, then the proposal was added to the Cabinet Meeting's agenda.

In a case of rejection, the material was referred back to the relevant EWG's desk. In sum, the working method seems to imply an asymmetric two-way interaction, whereby the main route of interaction is top-down 
(i.e. the implementation of the measures of the SKP), but there are significant bottom-up elements primarily in relation to the elaboration of ways and details of the foreseen decisions or legal measures to be implemented.

While the processes at the higher level of the SKWG were strongly regulated, the lower (EWG) level processes were largely ad hoc and informal, often depending on the leadership of the given EWG. Participants on this level were relatively free to express their own, possibly dissenting, viewpoints. Moreover, contrary to the high-level working group, some extent of freedom from top-down control existed in such matters as inviting members to, and participating in, the EWGs.

The pattern of decision-making in the SKWG thus exhibited important differences from the 'normal' mode of administrative consultation described earlier. Since the specific measures translating the individual items of the SKP into tangible pieces of legislative measures were constructed by the EWGs, the ministry departments in charge of the given issue did not participate in the decision-making process at all. Furthermore, they were only informed about the very decision ex post.

In addition to the high-level, political decision makers, EWGs had participation from a handful of usually high-quality policy experts. The administrative apparatuses and experts of the affected ministries were, however, largely excluded from the EWGs' operation. Consequently, the expertise and information possessed by the 'old' line ministry apparatuses were omitted from the entire decision-making process.

On the basis of available information it seems that this rather closed mode of operation was chosen because it ensured the availability of - at least to some extent - vital policy knowledge and information. More importantly, on the other hand, it also minimized the number and scope of those closely involved. This was expected to help avoid unnecessary political costs by minimizing the risk of leaking information on policy alternatives under consideration, and their severe consequences, out to the broader public.

\section{Main impacts and effects}

There is little systematic evidence available on the impacts and effects of the SKWG. In terms of evaluating the SKWG by the success of its key policy goal (the elaboration of austerity measures and the actual rebalancing of the budget, as a result of those measures), one should note that the task was difficult and the planned work schedule extremely tight.

According to plans, 11 subgroups (expert working groups) of the SKWG were expected to elaborate the required legal measures by 1 July 2011, but only four of them succeeded. ${ }^{2}$ By the end of the year, only four more subgroups were able to complete their task. No substantive improvements were achieved in such weighty areas 
as the restructuring of the railways corporation and the electronic road toll system (the latter was only implemented as late as Summer 2013). The cost-saving measures elaborated by the SKWG in 2011 were supposed to generate savings from financial year 2012 and according to the Cabinet's prepared forecast for one year later, 83 per cent of the 550 billion HUF correction was going to be achieved (Government of Hungary, 2012). Although the actual budgetary effect of the SKP (and the subsequent SKP 2.0, launched early 2012) is difficult to assess, overall a significant rebalancing of the current account has been achieved indeed, keeping the deficit below 3 per cent for two consecutive years.

In the summer of 2013, the European Commission suspended the excessive deficit procedure against Hungary. Soon thereafter, the country repaid the loans used from the IMF/EU standby arrangement. This rosy picture was yet still darkened by the significant tax burdens having appeared in a variety of important economic sectors, while possibly having a significant negative effect on the following growth and the investment period. In the second quarter of 2013 the public debt rate, however, still exceeded 80 per cent of the GDP, which was identical to the case at the beginning of the election cycle.

Analysing the SKWG arrangement from the perspective of transparency, the picture is definitely less than ideal. All internal processes and documents were confidential throughout the entire process. Neither conflicts nor preliminary ideas were publicly circulated. This rather closed, secretive and low-transparency operation triggered strong criticisms by the officials and experts excluded from the process and the practice can be seen as inferior to the one employed by the previous cabinet immediately after the outbreak of the 2008 crisis.

Yet another key difference between earlier modes of decision-making on the one hand, and the SKWG mode of operation on the other, relates to the role played by the seasoned, sector-specific apparatuses - that is, units in line ministries and central agencies subordinated to, and working in close cooperation with them. An illustrative example of such sectoral apparatuses may be the higher education sector comprising the Section for Higher Education Policy within the Ministry of National Resources and the subordinated Agency for Education. The decreasing role of these units - and the bureaucrats working in them - can best be understood in a somewhat broader temporal and functional perspective.

Already since the early 2000s, a general tendency of decreasing involvement of ministry apparatuses in policy formulation began to occur. Instead, key policy decisions were increasingly drafted by entities such as experts and think tanks rather than the aforementioned apparatuses. However, once elaborated, these proposals were subject to open debate and deliberation, more or less along the lines of the traditional administrative 
consultation process described earlier. Consequently, politicians/decision makers met already relatively consensual policy proposal agreements. This ensured that the decisions made were accepted and perceived as legitimate by the affected ministry apparatuses and - importantly - significantly decreased the risk of adopting unfounded and, thus, unfeasible decisions.

However, the trend of diminishing the involvement of sectoral apparatuses in policy formulation seriously accelerated in the post-2010 era when ministry units were given ready-made decisions, already elaborated to substantial detail. As such, the changing locus of decision-making in the SKWG operation reinforced and accelerated a broader trend of an ever-decreasing role of influence played by the seasoned bureaucracy in policy formulation. This may carry various dangers, as not only the quality of decisions is substantially threatened by the exclusion of their technical expertise, but a lack of politicians' confidence in bureaucracy leads to low morale and a mass exodus of experienced, high-quality civil servants who are often replaced by politically loyal, but technically incompetent employees.

\section{Lessons learned and policy implications}

On the basis of the evidence presented earlier one may conclude that a SKWG-type committee may be a functional instrument of coordination under pressing circumstances and conditions of crisis management. However, some possible limitations and problems related to the particular manner in which the SKWG was set up and operated may be also identified.

First, the entire operation of the SKWG was oriented towards producing (draft) legal measures as its output. A consideration of implementation, with all resource planning, logistical and practical aspects, let alone monitoring of processes and outputs/outcomes, remained entirely absent from the practice. This feature of the policy process is, however, quite characteristic for the entire Hungarian policy style, and is highly detrimental to its effectiveness.

Second, transparency and participation of societal actors in the decision-making was kept at a practically non-existent level. Moreover, the insights and information of line bureaucratic apparatuses remained almost entirely unutilized, too. These features seriously threatened the quality as well as the legitimacy of the decisions made.

Whether and how these two aspects could have been incorporated in the SKWG setup remains uncertain. In particular, the lack of transparency and participation seems to have been a deliberate strategy to minimize political opposition and political costs of hard or otherwise unfavourable decisions. In a sense, the 
SKWG can be seen as a specific manifestation of a broader ambition of political leadership to change the basic character of decision-making and policy coordination based on the traditional model of administrative consultation (see also Sárközy 2012). Other more permanent, and possibly more destructive, instruments to solve these problems include the widespread practice of initiating key governmental legislative changes by concealing them as bills of individual MPs, thereby allowing the government to avoid the lengthy administrative and societal consultation processes and implement key legislative changes overnight, sometimes in the literal sense of the word. A spectacular example of this is the rough changes to the Civil Service Law put through a few weeks after the inauguration of the new Cabinet in Summer 2010.

It may nevertheless be possible to improve future SKWG-like arrangements by incorporating more transparency and - administrative as well as societal - participation, and more in-depth follow-up on implementation and performance in their operation.

\section{References}

Bouckaert, G.B., G. Peters and K. Verhoest (2010) The Coordination of Public Sector Organizations: Shifting Patterns of Public Management, Basingstoke/New York: Palgrave.

Government of Hungary (2011) Széll Kálmán Terv, http://www.kormany.hu/download/4/d1/20000/Sz\%C3\%A911\%20K\%C3\%A11m\%C3\%A1n\% 20Terv.pdf, accessed 12 August 2013.

Government of Hungary (2012) Széll Kálmán Terv 2.0, http://www.kormany.hu/download/3/e8/80000/1A_k\%C3\%B6vetkez\%C5\%91_1\%C3\%A9p\%C3\%A9s\%20\%28SzKT\%2020\%29.pdf, accessed 12 August 2013.

Hajnal, G. (2010) 'Failing Policies or Failing Politicians? Policy Failures in Hungary', World Political Science Review, 6(1), Article 13.

Hajnal, G. and É. Kovács (2013) Analyzing the Motives of Reforming Central Government Coordination in Hungary: A Case Study of One-Stop-Government Reforms, IRSPM, XVII, Annual Conference, Prague, Czech Republic, 10-12 April 2013.

Hajnal, G. and S. Csengődi (2014) 'When Crisis Hits Superman: Change and Stability of Political Control and Politicization in Hungary', Halduskultuur (in press).

Kornai, J. (2012) 'Centralization and Market Economy in Hungary', CeSifo Forum, 13(1), 47-59. 
6, P. (2004) 'Joined-Up Government in the Western World in Comparative Perspective: A Preliminary Literature Review and Exploration', Journal of Public Administration Research and Theory, 14(1), 103-36.

Sárközy, T. (2012) Magyarország Kormányzása, 1978-2012, Budapest: Park Kiadó.

Scheppele, K.L. (2013) 'The Rule of Law and the Frankenstate: Why Governance Checklists Do Not Work', Governance, 26(4), 559-62.

Thompson, G., J. Frances, R. Levacic and J. Mitchell (1998) (eds) Markets, Hierarchies and Networks. The Coordination of Social Life, London: Sage.

${ }^{1}$ FIDESZ: Alliance of Young Democrats, KDNP: Christian-Democratic People's Party.

2 http://www.origo.hu/gazdasag/hirek/20110622-szell-kalmanterv-alacsonyra-tett-leceket-ugrik-ata-kormany.html, accessed 31 July 2013. 